\title{
1 Assessing the effectiveness of a three-stage on-farm biobed in 2 treating pesticide contaminated wastewater
}

3 Richard J. Cooper* ${ }^{1}$, Peter Fitt ${ }^{1}$, Kevin M. Hiscock ${ }^{1}$, Andrew A. Lovett ${ }^{1}$, Lee Gumm ${ }^{1}$, Steve J. 4 Dugdale $^{1}$, Justin Rambohul ${ }^{2}$, Antony Williamson ${ }^{2}$, Lister Noble ${ }^{3}$, James Beamish ${ }^{4}$, Poul 5 Hovesen $^{4}$

$6{ }^{1}$ School of Environmental Sciences, University of East Anglia, Norwich Research Park, Norwich, NR4 7TJ, UK

72 Environment Agency, Deanery Road, Bristol, BS1 5AH, UK

$8{ }^{3}$ Farm Systems \& Environment, Low Road, Wortwell, Harleston, IP2O OHJ, UK

$9 \quad{ }^{4}$ Salle Farms Co. Ltd, Manor Farm, Salle, Reepham, NR10 4SF, UK

$10{ }^{*}$ Correspondence: Richard.J.Cooper@uea.ac.uk

\section{Abstract}

Agricultural point source pesticide pollution arising from contaminated machinery washings and accidental spillages pose a significant threat to river water and groundwater quality. In this study, we assess the effectiveness of a three-stage on-farm biobed for treating pesticide contaminated waste water from a large $\left(20 \mathrm{~km}^{2}\right)$ commercial arable estate. The facility consisted of an enclosed machinery wash-down unit (stage 1), a $49 \mathrm{~m}^{2}$ lined compost-straw-topsoil biobed (stage 2), and a $200 \mathrm{~m}^{2}$ drainage field with a trickle irrigation system (stage 3). Pesticide concentrations were analysed in water samples collected fortnightly between November 2013 and November 2015 from the biobed input and output sumps and from 20 porous pots buried at $45 \mathrm{~cm}$ and $90 \mathrm{~cm}$ depth within the drainage field. The results revealed that the biobed removed $68-98 \%$ of individual pesticides within the contaminated washings, with mean total pesticide concentrations reducing by $91.6 \%$ between the biobed input and output sumps. Drainage field irrigation removed a further $68-$ $99 \%$ of individual pesticides, with total mean pesticide concentrations reducing by $98.4 \%$ and $97.2 \%$ in the $45 \mathrm{~cm}$ and $90 \mathrm{~cm}$ depth porous pots, respectively. The average total pesticide concentration at $45 \mathrm{~cm}$ depth in the drainage field $\left(57 \mu \mathrm{g} \mathrm{L}^{-1}\right)$ was 760 times lower than the mean concentration recorded in the input sump $\left(43,334 \mathrm{\mu g} \mathrm{L}^{-1}\right)$. There was no evidence of seasonality in the efficiency of biobed pesticide removal, nor was there evidence of a decline in removal efficiency over the twoyear monitoring period. However, higher mean total pesticide concentrations at $90 \mathrm{~cm}\left(102 \mu \mathrm{g} \mathrm{L}^{-1}\right)$ relative to $45 \mathrm{~cm}\left(57 \mathrm{~g} \mathrm{~L}^{-1}\right)$ depth indicated an accumulation of pesticide residues deeper within the soil profile. Overall, the results presented here demonstrate that a three-stage biobed can successfully reduce pesticide pollution risk from contaminated machinery washings on a commercial farm. 
Keywords: Biobed; pesticide; herbicide; biodegradation; water quality; arable

34

\section{Introduction}

The widespread use of pesticides in agriculture to kill plant and insect pests which would otherwise reduce crop yields has been instrumental in enhancing global agricultural productivity since the mid$20^{\text {th }}$ century (Oerke and Dehne, 2004; Oerke, 2005; Clarke et al., 2011; Popp et al., 2013). However, the harmful environmental impacts of applying toxic chemicals across large areas of the planet's surface, particularly on the aquatic environment, are coming under increasing scrutiny (Skinner et al., 1997; DeLorenzo et al., 2001; Schwarzenbach et al., 2010). High profile cases, such as the effect of the insecticide DDT on the hatching success of raptors in the 1960s and 1970s, brought into focus the potential for pesticides to bio-accumulate through the food chain and negatively impact upon non-target species (Ames, 1966; Connell, 1988; Arnot and Gobas, 2006). Similarly, recent research has linked the use of neonicotinoid insecticides to the decline of bee populations in Europe and North America (Blacquiere et al., 2012; Whitehorn et al., 2012). Studies have also highlighted the significant economic costs associated with removing pesticides from drinking water. Between 1991 and 2000, water companies in the United Kingdom spent $f 2$ billion treating pesticide contaminated water supplies (Jess et al., 2014), whilst in the United States the deleterious impacts of pesticide use were estimated to cost $\$ 9.6$ billion in 2005 alone (Pimentel, 2005).

In order to tackle pesticide pollution, a range of national and international legislation is currently in force. Under the EU Water Framework Directive (2000/60/EC), specifically the Drinking Water (98/83/EC) and Groundwater (2006/118/EC) Directives, European Union member states must ensure that no individual pesticide concentration in drinking water at the tap exceeds $0.1 \mu \mathrm{g} \mathrm{L}^{-1}$ and total pesticide concentrations should not exceed $0.5 \mu \mathrm{g} \mathrm{L} \mathrm{L}^{-1}$. Additionally, the Pesticides Framework Directive $(2009 / 128 / E C)$ aims to reduce the damage caused by pesticides through the adoption of sustainable usage practices. In the United States, similar legislation exists under the Safe Drinking Water Act (1974) which places individual concentration limits on specific pesticides.

Pesticide pollution can either arise from diffuse sources, such as spray drift, leaching and overland flow, or from point sources, such as accidental spillages, leakages from equipment or from contaminated machinery washings (Carter, 2000; De Wilde et al., 2007). Whilst diffuse sources can in part be reduced by behavioural changes, such as timing of spraying to avoid periods of wet and windy weather to limit pesticide mobility, biobeds have emerged as a potentially important 
mitigation strategy for dealing with point source pollution (Fogg et al., 2003a; Reichenberger et al., 2007; Karanasios et al., 2010; Omirou et al., 2012).

The biobed concept originated in Sweden in the 1990s as a way of using microbial activity to degrade waste pesticide residues (Torstensson, 2000). A biobed is essentially a moderately sized pit (typically tens of cubic metres in volume) which can be lined or unlined and is filled with a 1:2:1 matrix of compost, straw and topsoil. The surface is covered with grass and onto this the waste pesticide residues are deposited. In principle, microorganisms (e.g. bacteria and fungi) within the biobed matrix chemically and physically interact with the pesticides leading to structural changes and/or complete degradation (Pinto et al., 2016). To work effectively, the biobed mixture needs to have high pesticide absorption capacity and be able to facilitate high rates of microbial activity (Castillo et al., 2008). For this reason, straw is included to enhance microbial activity, particularly that of lignindegrading fungi (e.g. white rot fungi) which produce phenoloxidase enzymes that have a broad specificity and are thereby able to degrade a wide range of pesticide residues (Bending et al., 2002). Soil is included to increase the sorption capacity of the matrix material so that it holds onto the pesticides and also provides a source of microorganisms for biodegradation. Lastly, compost is added to increase sorption capacity, improve moisture content and decrease the $\mathrm{pH}$ to make conditions favourable for fungi growth. The surface grass layer aids water regulation and prevents surface crusting, thus limiting the formation of cracks that would open up preferential pathways for pesticides to escape the biobed prior to degradation (Fogg et al., 2004; Castillo and Torstensson, 2007; Castillo et al., 2008). In lined biobed systems, common in the United Kingdom (UK), the leachate is typically collected from the bottom of the biobed and re-used for either irrigation, sprayer washing or as a carrier for further herbicide applications. Irrigation can be on infield crops or a designated drainage area. In order to minimise pollution risk and comply with UK environmental protection legislation, the drainage area must be vegetated, be neither frozen or water logged, be $>10 \mathrm{~m}$ away from any surface waterbody, be $>50 \mathrm{~m}$ from any spring, well or borehole not used for domestic supply or food production, and be $>250 \mathrm{~m}$ away from any borehole that is used for domestic supply or food production (Environment Agency, 2007).

Established in 2010, the River Wensum Demonstration Test Catchment (DTC) project is a part of a UK government funded initiative to evaluate the extent to which on-farm mitigation measures can be employed to cost effectively reduce the impacts of agricultural pollution on river ecology whilst maintaining food production capacity (Outram et al., 2014). Draining a catchment area of $660 \mathrm{~km}^{2}$ in Norfolk, UK, of which $63 \%$ is arable land, the River Wensum supplies drinking water for the city of Norwich and is affected by agricultural pesticide pollution. A small unpublished water quality 
monitoring study carried out at 20 locations on the River Wensum over a 16-week period in autumn 2012 , revealed that $23 \%$ of samples contained individual pesticide concentrations greater than the $0.1 \mu \mathrm{g} \mathrm{L}^{-1}$ drinking water limit. Five key pesticides (metaldehyde, metazachlor, dimethenamid, flufenacet and propyzamide) accounted for $90 \%$ of all detected compounds, with $21 \%$ of samples containing metaldehyde concentrations $>1 \mu \mathrm{L} \mathrm{L}^{-1}$ (further details of this study can be found in the electronic supplementary material). Partly in response to this pesticide pollution pressure, an onfarm biobed unit capable of treating contaminated machinery washings was installed at Manor Farm, Salle, in the Blackwater sub-catchment of the River Wensum. This was part of a trial package of on-farm mitigation measures, co-funded under the Catchment Sensitive Farming (CSF) initiative (Natural England, 2014), aimed at reducing agricultural pollution.

The primary objectives of this paper are as follows:

(i) To assess the efficiency of the Manor Farm biobed at reducing pesticide concentrations in agricultural machinery washings;

(ii) To assess the effectiveness of drainage field irrigation at further reducing pesticide concentrations in biobed leachate;

(iii) To determine if biobed pesticide removal is more efficient for certain types of pesticide;

(iv) To assess temporal variability in the effectiveness of the biobed.

\section{Methods}

\subsection{Study Location}

This study focuses upon a biobed unit installed in 2013 at Manor Farm, Salle Park Estate, Norfolk, UK $\left(52^{\circ} 46^{\prime} 57^{\prime \prime} \mathrm{N}, 01^{\circ} 08^{\prime} 07^{\prime \prime} \mathrm{E}\right)$. The large, commercial Salle Park Estate covers $20 \mathrm{~km}^{2}$ of which $79 \%$ is intensive arable land managed with a seven-year crop rotation of winter wheat, winter and spring barley, winter oilseed rape, spring beans and sugar beet. The estate also comprises $15 \%$ improved grassland, $5 \%$ mixed woodland and 1\% rural settlements. Across the estate, 16,387 litres of concentrated liquid pesticide and 1,230 kg of solid pesticide granules were applied in 2014, the majority of which was applied during spring (March - May). Prior to the installation of the biobed, the risk of pesticide pollution occurring was relatively high. Farm machinery was washed down in the farmyard on concrete hard standing and the wastewater was collected in a drain with an isolation 
valve from where it was subsequently transported to a designated disposal area $0.8 \mathrm{~km}$ from the farm. However, the drain isolation valve was manually operated and human error could result in the contaminated washings discharging directly into a nearby pond.

\subsection{Biobed Facility}

The Manor Farm biobed facility consists of three main components (Figures 1 and 2):

(i) Wash-down unit: a $20 \mathrm{~m} \times 9 \mathrm{~m}$ enclosed concrete wash-down unit is used to both remove pesticides residues from farm machinery and to contain any pesticides spilt during the filling of the pesticide sprayer. A drain running down the centre of the unit channels contaminated washings into a concrete storage tank (the input sump);

(ii) Biobed: the biobed itself is an uncovered, indirect, lined (impermeable geomembrane) design covering an area of $49 \mathrm{~m}^{2}(7 \mathrm{~m} \times 7 \mathrm{~m})$ to a depth of $1.2 \mathrm{~m}$, thus providing a large surface area for biological and photo-degradation The organic bio-mix matrix material is composed of a 1:2:1 mix of peat-free compost, chopped wheat/barley straw and local topsoil. The surface is seeded with grass. Contaminated water from the input sump is pumped onto the biobed surface via a trickle irrigation system, with the leachate collected at the base of the biobed in a concrete output sump;

(iii) Drainage field: the leachate from the output sump is pumped onto a $200 \mathrm{~m}^{2}(20 \mathrm{~m} \times 10$ $\mathrm{m}$ ) drainage field via a second trickle irrigation system buried just below the surface to promote further removal of residual pesticide residues. This drainage field is covered with grass and is surrounded by seven mature trees. A network of 20 porous pots were installed ( $30^{\circ}$ angle) across the drainage area at $45 \mathrm{~cm}$ and $90 \mathrm{~cm}$ depth (ten pots for each) to monitor soil water pesticide concentrations at depth for signs of further removal or accumulation. As far as the authors are aware, this is the first time that pesticide removal in a drainage field on a commercial farm has been routinely monitored.

The biobed is designed to treat $>15,000 \mathrm{~L}$ of contaminated wastewater from the wash-down unit per year. The trickle irrigation pumps are controlled by float-switches within the input and output sumps so that irrigation commences automatically once the water depth within the sumps has reached a predefined level. During the winter, the irrigation systems are switched off to prevent ice damage. 


\subsection{Sample Collection}

158

159

160

161

162

163

164

165

166

167

168

169

170

171

172

173

174

175

176

177

178

179

Water samples were collected from the input and output sumps and the $45 \mathrm{~cm}$ and $90 \mathrm{~cm}$ porous pots at approximately two week intervals between November 2013 and November 2015. No sampling took place between June 2014 and November 2014 due to a hiatus in funding. On each sampling occasion eight water samples were collected to enable a range of analyses - three from each of the input and output sumps and one each from the $45 \mathrm{~cm}$ and $90 \mathrm{~cm}$ porous pots. Water from the sumps was collected using a stainless steel bucket lowered into the chambers on a chain and was decanted into a $1 \mathrm{~L}$ glass bottle (sample code $=$ PESTP) and two $250 \mathrm{~mL}$ polyethylene terephthalate (PET) bottles for each sump. To preserve the samples, one PET bottle had $2 \mathrm{~mL}$ of 3 molar formic acid added (HERBP), whilst the other contained $2 \mathrm{~mL}$ of 2.65 molar formic acid and 5 molar ammonium acetate (URON). For the drainage field, each $45 \mathrm{~cm}$ and $90 \mathrm{~cm}$ porous pot was put under vacuum for 20 minutes to extract soil water. Recovered soil water was bulked together to produce a single sample for each depth and was decanted into a $250 \mathrm{~mL}$ PET bottle containing $2 \mathrm{~mL}$ of 3 molar formic acid preservative (HERBP). The volume of soil water collected varied seasonally depending on soil moisture conditions, with up to $200 \mathrm{~mL}$ collect during the winter and $<50 \mathrm{~mL}$ collected during the summer. Throughout summer and autumn 2015, dry soil conditions meant no samples could be collected from the $45 \mathrm{~cm}$ porous pots. Note that in any given week, samples collected from the input sump, output sump and the drainage field did not correspond to the same body of contaminated water. Instead, samples collected from the drainage field corresponded to water that was in the output sump several days/weeks prior to sampling.

\subsection{Sample Analysis}

All samples were analysed by the Environment Agency's National Laboratory Service. Three different analytical techniques were employed to determine a wide variety of pesticide compounds:

(i) Phenoxy acidic herbicides (HERBP): a $1000 \mu \mathrm{L}$ aliquot was transferred into a silanised vial and an internal standard was added. $400 \mu \mathrm{L}$ of the sample was then injected into a high performance liquid chromatograph (HPLC) interfaced to a triple quadrupole mass spectrometer (TQMS) operated in positive and negative atmospheric pressure electrospray 
mode. Tandem mass spectroscopy data (MS/MS) were acquired in multiple reaction monitoring mode;

(ii) Phenyl urea herbicides, $n$-methyl carbamates, fungicides and asulam (URON): a $1000 \mu \mathrm{L}$

In total, 86 pesticides were detected and here we primarily focus on 15 compounds which were regularly used, had high input concentrations $\left(>100 \mu \mathrm{g} \mathrm{L}^{-1}\right)$ and/or are CSF key indicator pesticides. The physico-chemical properties of these pesticides, which are all herbicides and which accounted for $\sim 98.6 \%$ of all compounds measured in the input sump, are presented in Table 1 . Insufficient water was collected from the drainage field to enable the full suite of analyses to be carried out and therefore the porous pot analysis was restricted to a smaller number of compounds (HERBP only).

\section{Results}

\subsection{Total Pesticide Concentration}

206

The total concentrations for all 86 pesticides measured at the four monitoring points between November 2013 and November 2015 are shown in Figure 3. Mean pesticide concentrations over this period were: $43,334 \mu \mathrm{g} \mathrm{L}^{-1}$ (range $=1037-508,873 \mu \mathrm{g} \mathrm{L}^{-1}$ ) in the input sump; $3647 \mu \mathrm{g} \mathrm{L}^{-1}(47-42,260$ $\left.\mu \mathrm{g} \mathrm{L}^{-1}\right)$ in the output sump; $57 \mu \mathrm{g} \mathrm{L}^{-1}\left(0.5-192 \mu \mathrm{g} \mathrm{L} \mathrm{L}^{-1}\right)$ in the $45 \mathrm{~cm}$ depth porous pots; and $102 \mu \mathrm{g} \mathrm{L}^{-1}$ (2-396 $\left.\mathrm{g} \mathrm{L} \mathrm{L}^{-1}\right)$ in the $90 \mathrm{~cm}$ depth porous pots. Overall, this corresponds to a $91.6 \%$ reduction in pesticide concentration between the biobed input and output sumps, with a further $98.4 \%$ and 97.2\% reduction between the output sump and the $45 \mathrm{~cm}$ and $90 \mathrm{~cm}$ drainage field porous pots, respectively. Substantial temporal variability in the input sump concentrations reflect both variations in the amount of pesticide being applied across the farm at any one time and in the amount of water 
used during the washing of farm machinery (i.e. lower pesticide concentrations result when more water is used). Similarly, fluctuations in the output sump and porous pot concentrations will also reflect variability in precipitation which has the potential to both dilute and flush out pesticide residues within the biobed and drainage field.

\subsection{Individual Pesticide Concentrations}

Individual pesticide concentration data for the 15 key pesticides are presented in Table 2 . The highest mean pesticide concentration recorded in the input sump $\left(26,935 \mu \mathrm{g} \mathrm{L}^{-1}\right)$ was for ethofumesate, a widely applied herbicide to kill grass and broadleaf weeds in sugar beet crops. The lowest mean concentration $\left(15.3 \mu \mathrm{g} \mathrm{L}^{-1}\right)$ recorded was for carbetamide, a grass/broadleaf herbicide applied to oilseed rape. The efficiency of individual pesticide reduction between the input and output sumps ranged from $97.6 \%$ for propyzamide to $68.4 \%$ for metazachlor, with seven out of 15 pesticides achieving $>90 \%$ reduction in mean concentration. Mean concentrations in the $45 \mathrm{~cm}$ depth drainage field porous pots varied between $1.1 \mu \mathrm{g} \mathrm{L}^{-1}$ for bromoxynil and MCPA, to $9.3 \mu \mathrm{g} \mathrm{L}^{-1}$ for fluroxypyr. Similarly, in the $90 \mathrm{~cm}$ porous pots, bromoxynil and MCPA had the lowest mean concentrations $\left(1.6 \mu \mathrm{g} \mathrm{L}^{-1}\right)$, whilst clopyralid had the highest concentration $(16.2$ $\left.\mu \mathrm{g} \mathrm{L}^{-1}\right)$. The efficiency of pesticide removal between the output sump and the $45 \mathrm{~cm}$ porous pots ranged from $99.0 \%$ for $2,4-\mathrm{D}$ to $77.1 \%$ for MCPA, whilst in the $90 \mathrm{~cm}$ porous pots efficiencies ranged from $97.0 \%$ for $2,4-D$ to $68.3 \%$ for dicamba.

\section{Discussion}

\subsection{Biobed Efficiency}

The biobed proved to be highly effective in reducing the concentrations of pesticide within the contaminated machinery washings, lowering total pesticide concentrations by an average of $91.6 \%$. This compares with pesticide removal efficiencies of $52-100 \%$ recorded for a wide range of chemicals in other biobed studies conducted across Europe (De Wilde et al., 2007). Nevertheless, the mean total pesticide concentration $\left(3647 \mu \mathrm{g} \mathrm{L}^{-1}\right)$ and the mean concentrations of individual pesticides (3-1755 $\mathrm{g} \mathrm{L} \mathrm{L}^{-1}$ ) within the output sump remained sufficiently large to pose an environmental risk. These output concentrations are consistent with the results of similar studies assessing biobed removal efficiencies (e.g. Spliid et al., 2006). Irrigation of the biobed leachate in the 
drainage field was therefore necessary for promoting further pesticide removal. In the top $45 \mathrm{~cm}$ of the soil, total pesticide concentrations were reduced by $98.4 \%$ to $57 \mathrm{\mu g} \mathrm{L}^{-1}$, whilst individual pesticide concentrations were reduced by $77.1-99.0 \%$ to $1.1-9.3 \mu \mathrm{g} \mathrm{L}^{-1}$. These results clearly demonstrate that collecting the leachate from the biobed output sump and applying it onto a drainage field to allow further pesticide removal within the soil profile is essential to reduce concentrations down to more environmentally acceptable levels and represents a significant reduction in risk over the previous farm practice described in Section 2.1.

\subsection{Individual Pesticide Removal}

With the mean pesticide removal efficiency varying by $29.2 \%$ between the best (propyzamide) and worst (metazachlor) performing herbicide, it is apparent that the degree of removal achieved is dependent upon the chemical structure of the pesticides used. The environmental mobility and persistence of any given pesticide is primarily controlled by its soil sorption characteristics, water solubility and half-life (Arias-Estévez et al., 2008). Highly soluble pesticides with low sorption capacity will tend to move more quickly through the biobed matrix than pesticides with high sorption capacity, and this reduced residence time will diminish the opportunities for microorganisms to degrade these chemicals (i.e. bioavailability will be reduced) (Spliid et al., 2006; De Wilde et al., 2007). Furthermore, most pesticides are degraded by co-metabolic processes. By metabolising constituents within the biobed (e.g. straw), bacteria and fungi produce enzymes which are able to break down toxic chemicals that they otherwise would not be able to degrade (Castillo and Torstensson, 2007). However, different pesticide chemical structures have different susceptibility to the oxidative enzymes produced by bacteria and fungi (Ferris and Lichtenstein, 1980), and therefore even pesticides with a high sorption capacity that are retained within the biobed may experience low degradation rates.

Evidence of these processes can be seen in Figure 4, which shows the relationships between biobed removal efficiency and the typical soil sorption $\left(K_{o c}\right)$, water solubility and half-life $\left(\mathrm{DT}_{50}\right)$ values of the 15 pesticides monitored here (data from Lewis et al. (2016)). Despite considerable scatter, there is a positive linear relationship $\left(R^{2}=0.19, p=0.10\right)$ between soil sorption and removal efficiency, with five out of six pesticides with the highest sorption coefficients $\left(K_{o c}>100\right)$ having high removal efficiencies (>93\%). Similarly, there is a significant negative relationship $\left(R^{2}=0.28, p=0.04\right)$ between pesticide solubility and removal efficiency, with the six least soluble $\left(<440 \mathrm{mg} \mathrm{L}^{-1}\right)$ pesticides exhibiting the highest levels of removal $(>93 \%)$. A significant positive relationship $\left(R^{2}=\right.$ 
$2770.34, p=0.02$ ) is also apparent between removal efficiency and pesticide half-life, indicating that more persistent pesticides were removed from the leachate more readily than less persistent compounds. However, pesticide sorption coefficients are strongly and significantly correlated with both solubility $(r=-0.79, p<0.01)$ and $\mathrm{DT}_{50}(r=0.50, p<0.05)$ and this in part helps to explain the positive and negative relationships observed between removal efficiency and $\mathrm{DT}_{50}$ and solubility, respectively. In general, pesticides with higher soil sorption coefficients, lower solubility and longer half-lives experienced the greatest removal rates within the Manor Farm biobed.

\subsection{Pesticide Accumulation}

Although total pesticide concentrations were reduced by $98.4 \%$ between the output sump and the $45 \mathrm{~cm}$ porous pots, the mean total pesticide concentration in the $90 \mathrm{~cm}$ drainage field porous pots (102 $\mathrm{g} \mathrm{L} \mathrm{L}^{-1}$ ) was nearly double that recorded at $45 \mathrm{~cm}$ depth $\left(57 \mu \mathrm{g} \mathrm{L}^{-1}\right.$ ) (Figure 3). Similarly, all individual pesticide concentrations were higher at $90 \mathrm{~cm}$ depth compared with $45 \mathrm{~cm}$ (Table 2), indicating an accumulation of pesticides residues at depth within the drainage field. A potential explanation for this observation comes from examining $1 \mathrm{~m}$ depth soil cores taken from the drainage field during porous pot installation which revealed that a silty clay layer dominates the upper $0.5 \mathrm{~m}$ whereas sandier material dominates at 0.5-1.0 m depth (Lewis, 2011; Figure SM2 in supplementary material). The clay-rich surface layer would be expected to favour greater pesticide attenuation via sorption onto soil, thus lowering pesticide concentrations in the pore water extracted for analysis. Conversely, the sandier layer at depth would be expected to have lower sorption capacity, thus leaving higher pesticide concentrations in the pore water collected in the porous pots. Additionally, desiccation and fissuring of the surface clay-rich layer could form preferential flow paths deeper into the soil profile, potentially allowing the pesticide leachate to bypass the aerobic surface layers where most biological degradation occurs. Ultimately, these processes could result in the drainage field itself acting as a point source of pesticide pollution, particularly if interactions with groundwater increase the lateral mobility of the pesticide residues. These findings emphasise the importance of drainage field design and siting in maximising the removal of pesticides and minimising potential off-site transport.

\subsection{Temporal Trends}


Successful removal of pesticides within a biobed is dependent upon the biobed matrix supporting a high level of microbial activity and, as such, temperature and moisture content are important factors in determining biobed efficiency. A study by Castillo and Torstensson (2007) demonstrated higher rates of pesticide dissipation when the biobed temperature was at $20^{\circ} \mathrm{C}$ (compared to $5^{\circ} \mathrm{C}$ and $10^{\circ} \mathrm{C}$ ) and moisture levels were at $60 \%$ (compared to $30 \%$ or $90 \%$ ) of the water holding capacity. Therefore, it might be expected that greater pesticide removal will occur during the summer when temperatures are higher, provided the biobed matrix maintains high moisture content. However, there was no clear evidence of such a trend with the Manor Farm biobed (Figure 3), suggesting that temperature and moisture content may be secondary factors in determining the performance of operational biobeds when compared with laboratory studies. Mean pesticide removal efficiencies between the input and output sumps were 94.5\% during the winter (DJF), 97.5\% during the spring (MAM) and $92.5 \%$ during the summer (JJA). Only autumn (SON), with an efficiency of $75.1 \%$, had significantly lower pesticide removal. This was predominantly due to the very high concentrations of metazachlor recorded in the input (up to $73,900 \mu \mathrm{g} \mathrm{L}^{-1}$ ) and output (up to $27,900 \mu \mathrm{g} \mathrm{L}^{-1}$ ) sumps during September - October 2015 after spraying of the autumn sown oilseed rape crop. Prior to autumn 2015, concentrations of metazachlor in the input sump were relatively low (mean $=192 \mu \mathrm{g}$ $\mathrm{L}^{-1}$ ) and the efficiency of biobed removal was high (mean $=94.9 \%$ ). However, the removal efficiency declined sharply in autumn 2015 (mean $=63.4 \%$ ), indicating that the biobed was unable to cope with very high metazachlor loading. Although none of the other 14 pesticides analysed here demonstrated this behaviour, similar declines in removal efficiency due to high pesticide loadings have previously been reported in other biobed studies (Fogg et al., 2003b; Vischetti et al., 2008). The effect of poor metazachlor removal in autumn 2015 reduced the overall biobed total pesticide removal efficiency by $2.8 \%$, from $94.4 \%$ to $91.6 \%$.

In the UK, it is suggested that the entire biobed matrix is replaced every five years since decomposition of organic matter gradually reduces the efficiency of pesticide removal (Castillo et al., 2008). Over the two-year monitoring period of this study, there was no evidence of a reduction in the biobed performance, with mean biobed removal efficiencies of $91.1 \%$ prior to July 2014 and 91.6\% after December 2014.

\subsection{Biobed Maintenance}

The biobed facility required limited maintenance following its construction in 2013. The biobed matrix was topped up with fresh material in July 2015 after two years of operation as decomposition 
of organic material had reduced the depth of the bio-mix. At the same time, some re-profiling of the biobed surface was carried out to address slumping in one corner which was causing minor runoff away from the biobed onto the adjacent grassed area. Previous research by Fogg et al. (2004) found that uncovered lined biobeds treating large volumes of machinery washings, such as this one here, can become waterlogged without some form of water management, thus resulting in reduced microbial activity and lower rates of pesticide degradation. Some evidence of water accumulation on the surface of the Manor Farm biobed was observed during very heavy rainfall events, although such incidences were infrequent and of short duration. There was no evidence of reduced biobed performance during the winter when the matrix moisture content would be at its highest level. This confirms that the biobed design was appropriate for handling machinery washings from the Salle Park Estate.

\subsection{Implications and Economics}

The results presented here clearly demonstrate the effectiveness of a straw-compost-topsoil biobed at reducing pesticide residues in substantial volumes of contaminated water generated from machinery washings on a large, arable farm. It is also clear that further treatment of the biobed leachate by irrigating the contaminated water through the soil profile of a substantially sized drainage field is beneficial to further reduce pesticide concentrations down to environmentally acceptable levels. Furthermore, the enclosed sprayer wash-down area provides a secure environment when handling pesticide concentrate during sprayer filling operations, thus minimising the risk of accidental spillage leading to surface water contamination. Wider scale adoption of biobeds as an on-farm mitigation measure could therefore result in a significant reduction in point source pesticide pollution of streams and rivers draining agricultural catchments. Biobeds are effective in reducing the risks associated with farm pesticide spraying operations since they contain and breakdown pesticides in effluent that could otherwise escape the farm via drainage water. Hence, biobeds are an efficient pesticide reduction measure and are an important tool used by catchment level pollution reduction schemes such as Catchment Sensitive Farming (Environment Agency, 2014; Natural England, 2014). The farmers of the Salle Park Estate also reported that the three-stage biobed significantly improved the efficiency of pesticide handling operations, with pesticide dispensing, machinery washing and wastewater disposal now occurring at a single, purpose built facility.

Table 3 lists the approximate construction costs for the three main components of the Manor Farm biobed. Whilst total costs were $f 96,827$, the majority of this $(£ 90,454)$ was for building the large, 
insulated, wash-down unit and equipping it with mains electricity and steam cleaning equipment. Such a high quality design is not essential to achieve good operational performance and much simpler facilities would be more appropriate for wider deployment across multiple farms within a catchment. The cost of the biobed itself, which included the pipework, pumps, liner, matrix material and labour, was relatively inexpensive ( $£ 4311)$. Replenishment of the matrix material two years after construction cost $f 8 \mathrm{~m}^{-2}$. The cost of the drainage field infrastructure was approximately $f 1684$, of which the porous pots accounted for $£ 1466$. Installing porous pots in other commercial biobeds would not be necessary as their installation here was purely for research purposes. Much simpler designs could likely be constructed for $55000-10,000$, increasing the feasibility of uptake by a larger number of farms, particularly if such measures were financially incentivised under government agrienvironment schemes.

\section{Conclusion}

Pesticide pollution threatens the sustainable ecosystem functioning of rivers draining agricultural catchments and therefore mitigation measures are required to reduce the amount of pesticides entering freshwater environments. In this study, we have demonstrated how an on-farm biobed is capable of reducing the risk of point source pesticide pollution by substantially decreasing pesticide concentrations in large volumes of contaminated machinery washings from a $20 \mathrm{~km}^{2}$ arable estate. The three-stage biobed facility, consisting of an enclosed machinery wash-down unit, a $49 \mathrm{~m}^{2}$ lined compost-straw-topsoil biobed and a $200 \mathrm{~m}^{2}$ drainage field, provided an efficient and secure environment for pesticide handling and mixing operations, containing contaminated washings and removing waste pesticide residues. Water quality monitoring over a two-year period revealed individual pesticide concentrations reduced by $68-98 \%$ between the biobed input and output sumps, with mean total pesticide concentrations reducing by $91.6 \%$. Further treatment of the contaminated washings in the drainage field removed an additional $68-99 \%$ of individual residual pesticides, with total mean pesticide concentrations reducing by a further $98.4 \%$ and $97.2 \%$ in the 45 $\mathrm{cm}$ and $90 \mathrm{~cm}$ depth porous pots, respectively. Mean total pesticide concentrations at $45 \mathrm{~cm}$ depth $\left(57 \mu \mathrm{g} \mathrm{L}^{-1}\right)$ after drainage field irrigation were 760 times lower than that recorded in the untreated machinery washings $\left(43,334 \mu \mathrm{g} \mathrm{L} \mathrm{L}^{-1}\right)$. Although the treated effluent still requires careful handling to avoid contaminating freshwater bodies, this nevertheless represents a substantial reduction in groundwater pesticide pollution risk compared with the previous farm practice of disposing of untreated waste washings in a designated disposal area. The biobed has also reduced the risk of point source surface water pollution by removing reliance upon a manually operated isolation value 
to prevent contaminated washings discharging directly into a farm pond. No evidence of seasonality in the efficiency of pesticide removal was detected, nor was there any evidence of a decline in biobed performance over the two-year monitoring period. However, elevated pesticide concentrations at $90 \mathrm{~cm}$ depth within the drainage field potentially indicate an accumulation of pesticide residues deeper within the soil profile which could pose a risk to groundwater quality. Nevertheless, the results presented here clearly demonstrate the effectiveness of a three-stage onfarm biobed at reducing pesticide residues in substantial volumes of contaminated water generated from machinery washing on a large, commercial arable farm.

\section{Acknowledgements}

This research was part funded by the Department for Environment, Food and Rural Affairs (Defra) under the Demonstration Test Catchments initiative (WQ0212/LM0304). Additional funding came from a Natural England CSF capital grant. The authors would like to thank the Salle Park Estate for their cooperation with the installation and operation of the Manor Farm biobed. We also thank the Environment Agency for conducting the pesticide analysis, David Harris for providing the economic data, Simon Linford-Wood for providing the supplementary material, and Adam Wisher for producing Table 1 . We thank the anonymous reviewer whose constructive comments helped improve an earlier version of this manuscript.

\section{References}

Arias-Estévez, M., López-Periago, E., Martínez-Carballo, E., Simal-Gándara, J., Mejuto, J.C., GarcíaRío, L., 2008. The mobility and degradation of pesticides in soils and the pollution of groundwater resources. Agriculture, Ecosystem and Environment 123, 247-260. DOI: 10.1016/j.agee.2007.07.011.

Arnot, J.A., Gobas, F.A.P.C., 2006. A review of bioconcentration factor (BCF) and bioaccumulation factor (BAF) assessments for organic chemicals in aquatic organisms. Environmental Reviews 14, 257-297. DOI: 10.1139/a06-005.

Bending, G.D., Friloux, M., Walker, A., 2002. Degredation of contrasting pesticides by white rot fungi and its relationship with ligninolytic potential. FEMS Microbiology Letters 212, 59-63. DOI: 10.1111/j.1574-6968.2002.tb11245.x.

Blacquiere, T., Smagghe, G., van Gestel, C.A., Mommaerts, V., 2012. Neonicotinoids in bees: a review on concentrations, side-effects and risk assessment. Ecotoxicology 21, 973-992. DOI: 10.1007/s10646-012-0863-x. 
Carter, A.D., 2000. How pesticides get into water - and proposed reduction measures. Pesticide Outlook 11, 149-157.

Castillo, M.P., Torstensson, L., 2007. Effect of biobed composition, moisture, and temperature on the degredation of pesticides. Journal of Agricultural and Food Chemistry 55, 5725-5733. DOI: 10.1021/jf0707637.

Castillo, M.P., Torstensson, L., Stenström, J., 2008. Biobeds for environmental protection from pesticide use - a review. Journal of Agricultural and Food Chemistry 56, 6206-6219. DOI: 10.1021/jf800844x.

Clarke, J.H., Wynn, S.C., Twining, S.E., 2011. Impact of changing pesticide availability. Aspects of Applied Biology 106, 263-267. DOI:

Connell, D.W., 1988. Bioaccumulation behaviour of persistent organic chemicals with aquatic organisms. Reviews of Environmental Contamination and Toxicology 102, 117-154. DOI: 10.1007/978-1-4612-3810-2_3.

DeLorenzo, M.E., Scott, G.I., Ross, P.E., 2001. Toxicity of pesticides to aquatic microorganisms: a review. Environmental Toxicology and Chemistry 20, 84-98. DOI: 10.1002/etc.5620200108.

De Wilde, T., Spanoghe, P., Debaer, C., Ryckeboer, J., Springael, D., Jaeken, P., 2007. Overview of onfarm bioremediation systems to reduce the occurrence of point source contamination. Pest Management Science 63, 111-128. DOI: 10.1002/ps.1323.

Environment Agency, 2007. Guidance on using a lined biobed to dispose of agricultural waste consisting of non-hazardouse pesticide solutions or washings (Exemption 52). Bristol, England.

Environment Agency, 2014. Pesticide monitoring in catchment sensitive farming (CSF) river catchments: 2006-2013. Bristol, England.

Ferris, I.G., Lichtenstein, E.P., 1980. Interactions between agricultural chemicals and soil microflora and their effects on the degradation of $\left[\mathrm{C}^{14}\right]$-parathion in a cranberry soil. J Agric Food Chem 28, 1011-1019.

Fogg, P., Boxall, A., Walker, A., Jukes, A., 2003a. Pesticide degradation in a 'biobed' composting substrate. Pest Manag Sci 59, 527-537. DOI: 10.1002/ps.685.

Fogg, P., Boxall, A., Walker, A., 2003b. Degradation of pesticides in biobeds: the effect of concentration and pesticide mixtures. J Agric Food Chem 51, 5344-5349.

Fogg, P., Boxall, A., Walker, A., Jukes, A., 2004. Degradation and leaching potential of pesticides in biobed systems. Pest Manag Sci 60, 645-654. DOI: 10.1002/ps.826.

Jess, S., Kildea, S., Moody, A., Rennick, G., Murchie, A.K., Cooke, L.R., 2014. European Union policy on pesticides: implications for agriculture in Ireland. Pest Manag Sci 70, 1646-1654. DOI: 10.1002/ps.3801.

Karanasios, E., Tsiropoulos, N.G., Karpouzas, D.G., Ehaliotis, C., 2010. Degradation and adsorption of pesticides in compost-based biomixtures as potential substrates for biobeds in southern Europe. Journal of Agricultural and Food Chemistry 58, 9147-9156. DOI: 10.1021/jf1011853.

Lewis, M.A., 2011. Borehole drilling and sampling in the Wensum Demonstration Test Catchment. British Geological Survey Commissioned Report, CR/11/162, pp. 38.

Lewis, K.A., Tzilivakis, J., Warner, D., Green, A., 2016. An interational database for pesticide risk assessments and management. Human and Ecologcial Risk Assessment: An International Journal. DOI: 10.1080/10807039.2015.1133242.

Natural England, 2014. Catchment sensitive farming: evaluation report - phases 1 to 3 (2006-2014). Worcester, England. ISBN: 978-1-78367-155-7. 
Oerke, E.C., Dehne, H.W., 2004. Safeguarding production-losses in major crops and the role of crop protection. Crop Protection 23, 275-285. DOI: 10.1016/j.cropro.2003.10.001.

Oerke, E.C., 2005. Crop losses to pests. J Agr Sci 144:31-43. DOI:10.1017/S0021859605005708.

Omirou, M., Dalias, P., Costa, C., Papastefanou, C., Dados, A., Ehaliotis, C., Karpouzas, D.G., 2012. Exploring the potential of biobeds for the depuration of pesticide-contaminated wastewaters from the citrus production chain: laboratory, column and field studies. Environmental Pollution 166, 31-39. DOI: 10.1016/j.envpol.2012.03.001.

Outram, F.N., Lloyd, C.E.M., Jonczyk, J., Benskin, C.M.H., Grant, F., Perks, M.T., Deasy, C., Burke, S.P., Collins, A.L., Freer, J., Haygarth, P.M., Hiscock, K.M., Johnes, P.J., Lovett, A.L., 2014. Highfrequency monitoring of nitrogen and phosphorus response in three rural catchments to the end of the 2011-2012 drought in England. Hydrology and Earth System Sciences 18, 3429-3448. DOI: 10.5194/hess-18-3429-2014.

Pimentel, D., 2005. Environmental and economic costs of the application of pesticides primarily in the United States. Environ Dev Sus 7:229-252. DOI: 10.1007/s10668-005-7314-2.

Pinto, A.P., Rodrigues, S.C., Caldeira, A.T., Teixeira, D.M., 2016. Exploring the potential of novel biomixtures and Lentinula edodes fungus for the degradation of selected pesticides. Evaluation for use in biobed systems. Sci Total Environ 541, 1372-1381. DOI: 10.1016/j.scitotenv.2015.10.046.

Popp, J., Pető, K., Nagy, J., 2013. Pesticide productivity and food security. A review. Agronomy for Sustainable Development 33, 243-255. DOI: 10.1007/s13593-012-0105-x.

Reichenberger, S., Bach, M., Skitschak, A., Frede, H.G., 2007. Mitigation strategies to reduce pesticide inputs into ground- and surface water and their effectiveness: a review. Sci Total Environ 384, 1-35. DOI: 10.1016/j.scitotenv.2007.04.046.

Schwarzenbach, R.P., Egli, T., Hofstetter, T.B., von Gunten, U., Wehrli, B., 2010. Global Water Pollution and Human Health. Annual Review of Environment and Resources 35, 109-136. DOI: 10.1146/annurev-environ-100809-125342.

Spliid, N.H., Helweg, A., Heinrichson, K., 2006. Leaching and degredation of 21 pesticides in a fullscale model biobed. Chemosphere 65, 2223-2232. DOI: 10.1016/j.chemosphere.2006.05.049.

Torstensson, L., 2000. Experiences of biobeds in practical use in Sweden. Pesticide Outlook 11, 206211. DOI: $10.1039 / \mathrm{b} 008025 \mathrm{j}$.

Vischetti, C., Monaci, E., Cardinali, A., Casucci, C., Perucci, P., 2008. The effect of initial concentration, co-application and repeated applications on pesticide degradation in a biobed mixture. Chemosphere 72, 1739-1743. DOI: 10.1016/j.chemosphere.2008.04.065.

Whitehorn, P.R., O'Connor, S., Wackers, F.L., Goulson, D., 2012. Neonicotinoid pesticide reduces bumble bee colony growth and queen production. Science 336, 351-352. DOI: 10.1126/science.1215025. 
Table 1: Summary of the 15 pesticides analysed in the Manor Farm biobed, Salle, which were either regularly used, had high input concentrations $(>100 \mu \mathrm{g}$ $\mathrm{L}^{-1}$ ) or are CSF key indicator pesticides. Typical physico-chemical characteristics derived from Lewis et al. (2016).

\begin{tabular}{|c|c|c|c|c|c|c|c|}
\hline Pesticide & Formula & 2D Structure & Type & $\begin{array}{c}\text { Primary Crop } \\
\text { Use }\end{array}$ & $\begin{array}{c}\text { Soil Sorption } \\
\text { Coefficient } \\
\left(K_{o c} \mathrm{~mL} \mathrm{~g}^{-1}\right)\end{array}$ & $\begin{array}{c}\text { Solubility in } \\
\left.\text { Water ( } \mathrm{mg} \mathrm{L}^{-1}\right)\end{array}$ & $\begin{array}{l}\text { Half Life in Field } \\
\text { DT }_{50} \text { (days) }\end{array}$ \\
\hline Propyzamide & $\mathrm{C}_{12} \mathrm{H}_{11} \mathrm{Cl}_{2} \mathrm{NO}$ & & $\begin{array}{c}\text { Grass/broadleaf } \\
\text { herbicide }\end{array}$ & $\begin{array}{c}\text { Oilseed } \\
\text { rape/field beans }\end{array}$ & $\begin{array}{c}840 \\
\text { (Slightly mobile) }\end{array}$ & $\begin{array}{c}9 \\
\text { (Low) }\end{array}$ & $\begin{array}{c}56 \\
\text { (Moderately persistent) }\end{array}$ \\
\hline Ethofumesate & $\mathrm{C}_{13} \mathrm{H}_{18} \mathrm{O}_{5} \mathrm{~S}$ & & $\begin{array}{c}\text { Grass/broadleaf } \\
\text { herbicide }\end{array}$ & Sugar beet & $\begin{array}{c}55-500 \\
\text { (Moderately } \\
\text { mobile) }\end{array}$ & $\begin{array}{c}50 \\
\text { (Moderate) }\end{array}$ & $\begin{array}{c}37.8 \\
\text { (Moderately persistent) }\end{array}$ \\
\hline Bromoxynil & $\mathrm{C}_{7} \mathrm{H}_{3} \mathrm{Br}_{2} \mathrm{NO}$ & & $\begin{array}{l}\text { Broadleaf } \\
\text { herbicide }\end{array}$ & Cereals & $\begin{array}{c}302 \\
\text { (Moderately } \\
\text { mobile) }\end{array}$ & $\begin{array}{c}90 \\
\text { (Moderate) }\end{array}$ & $\begin{array}{c}8 \\
\text { (Non-persistent) }\end{array}$ \\
\hline $\begin{array}{l}\text { Metsulfuron- } \\
\text { methyl }\end{array}$ & $\mathrm{C}_{14} \mathrm{H}_{15} \mathrm{~N}_{2} \mathrm{O}_{6} \mathrm{~S}$ & & $\begin{array}{c}\text { Grass/broadleaf } \\
\text { herbicide }\end{array}$ & Cereals & $\begin{array}{c}120-320 \\
\text { (Moderately } \\
\text { mobile) }\end{array}$ & $\begin{array}{l}2,790 \\
\text { (High) }\end{array}$ & $\begin{array}{c}13.3 \\
\text { (Non-persistent) }\end{array}$ \\
\hline Chlorotoluron & $\mathrm{C}_{10} \mathrm{H}_{13} \mathrm{ClN}_{2} \mathrm{O}$ & & $\begin{array}{c}\text { Grass/broadleaf } \\
\text { herbicide }\end{array}$ & Cereals & $\begin{array}{c}196 \\
\text { (Moderately } \\
\text { mobile) }\end{array}$ & $\begin{array}{c}74 \\
\text { (Moderate) }\end{array}$ & $\begin{array}{c}34 \\
\text { (Moderately persistent) }\end{array}$ \\
\hline Chloridazon & $\mathrm{C}_{10} \mathrm{H}_{8} \mathrm{ClN}_{3} \mathrm{O}$ & & $\begin{array}{l}\text { Broadleaf } \\
\text { herbicide }\end{array}$ & Sugar beet & $\begin{array}{c}120 \\
\text { (Moderately } \\
\text { mobile) }\end{array}$ & $\begin{array}{c}422 \\
\text { (Moderate) }\end{array}$ & $\begin{array}{c}34.7 \\
\text { (Moderately persistent) }\end{array}$ \\
\hline Carbetamide & $\mathrm{C}_{12} \mathrm{H}_{16} \mathrm{~N}_{2} \mathrm{O}_{3}$ & & $\begin{array}{c}\text { Grass/broadleaf } \\
\text { herbicide }\end{array}$ & Oilseed rape & $\begin{array}{c}89 \\
\text { (Moderately } \\
\text { mobile) }\end{array}$ & $\begin{array}{l}3,270 \\
\text { (High) }\end{array}$ & $\begin{array}{c}8 \\
\text { (Non-persistent) }\end{array}$ \\
\hline
\end{tabular}




\begin{tabular}{|c|c|c|c|c|c|c|c|}
\hline Fluroxypyr & $\mathrm{C}_{7} \mathrm{H}_{5} \mathrm{Cl}_{2} \mathrm{FN}_{2} \mathrm{O}_{3}$ & & $\begin{array}{l}\text { Broadleaf } \\
\text { herbicide }\end{array}$ & Cereals & $\begin{array}{c}74 \\
\text { (Mobile) }\end{array}$ & $\begin{array}{l}6,500 \\
\text { (High) }\end{array}$ & $\begin{array}{c}51 \\
\text { (Moderately persistent) }\end{array}$ \\
\hline MCPA & $\mathrm{C}_{9} \mathrm{H}_{9} \mathrm{ClO}_{3}$ & & $\begin{array}{l}\text { Broadleaf } \\
\text { herbicide }\end{array}$ & Cereals & $\begin{array}{c}74 \\
\text { (Mobile) }\end{array}$ & $\begin{array}{l}29,390 \\
\text { (High) }\end{array}$ & $\begin{array}{c}25 \\
\text { (Non-persistent) }\end{array}$ \\
\hline Metazachlor & $\mathrm{C}_{14} \mathrm{H}_{16} \mathrm{ClN}_{3} \mathrm{O}$ & & $\begin{array}{c}\text { Grass/broadleaf } \\
\text { herbicide }\end{array}$ & Oilseed rape & $\begin{array}{c}54 \\
\text { (Mobile) }\end{array}$ & $\begin{array}{c}450 \\
\text { (Moderate) }\end{array}$ & $\begin{array}{c}6.8 \\
\text { (Non-persistent) }\end{array}$ \\
\hline Mecoprop & $\mathrm{C}_{10} \mathrm{H}_{11} \mathrm{ClO}_{3}$ & & $\begin{array}{l}\text { Broadleaf } \\
\text { herbicide }\end{array}$ & Cereals & $\begin{array}{c}47 \\
\text { (Mobile) }\end{array}$ & $\begin{array}{c}250,000 \\
\text { (High) }\end{array}$ & $\begin{array}{c}8.2 \\
\text { (Non-persistent) }\end{array}$ \\
\hline 2,4-D & $\mathrm{C}_{8} \mathrm{H}_{6} \mathrm{Cl}_{2} \mathrm{O}_{3}$ & & $\begin{array}{l}\text { Broadleaf } \\
\text { herbicide }\end{array}$ & Cereals & $\begin{array}{c}39.3 \\
\text { (Mobile) }\end{array}$ & $\begin{array}{r}24,300 \\
\text { (High) }\end{array}$ & $\begin{array}{c}28.8 \\
\text { (Non-persistent) }\end{array}$ \\
\hline Triclopyr & $\mathrm{C}_{7} \mathrm{H}_{4} \mathrm{Cl}_{3} \mathrm{NO}_{3}$ & & $\begin{array}{l}\text { Broadleaf } \\
\text { herbicide }\end{array}$ & Cereals & $\begin{array}{c}27 \\
\text { (Mobile) }\end{array}$ & $\begin{array}{c}440 \\
\text { (Moderate) }\end{array}$ & $\begin{array}{c}30 \\
\text { (Moderately persistent) }\end{array}$ \\
\hline Clopyralid & $\mathrm{C}_{6} \mathrm{H}_{3} \mathrm{Cl}_{2} \mathrm{NO}_{2}$ & & $\begin{array}{l}\text { Broadleaf } \\
\text { herbicide }\end{array}$ & $\begin{array}{c}\text { Cereals/oilseed } \\
\text { rape }\end{array}$ & $\begin{array}{c}5 \\
\text { (Very mobile) }\end{array}$ & $\begin{array}{c}143,000 \\
\text { (High) }\end{array}$ & $\begin{array}{c}11 \\
\text { (Non-persistent) }\end{array}$ \\
\hline Dicamba & $\mathrm{C}_{8} \mathrm{H}_{6} \mathrm{Cl}_{2} \mathrm{O}_{3}$ & & $\begin{array}{l}\text { Broadleaf } \\
\text { herbicide }\end{array}$ & Cereals & $\begin{array}{c}2 \\
\text { (Very mobile) }\end{array}$ & $\begin{array}{l}250,000 \\
\text { (High) }\end{array}$ & $\begin{array}{c}3.9 \\
\text { (Non-persistent) }\end{array}$ \\
\hline
\end{tabular}


Table 2: Mean concentration data for 15 pesticides which were either regularly used, had high input concentrations $\left(>100 \mu \mathrm{g} \mathrm{L}^{-1}\right)$ or are CSF key indicator pesticides. Data are for the period November 2013 to November 2015. The efficiency of the biobed sumps refers to the reduction in pesticide concentration between the input and output sumps. The efficiencies of the porous pots reflect the reductions in pesticide concentration between the output sump and the $45 \mathrm{~cm}$ and $90 \mathrm{~cm}$ porous pots. Missing values relate to non-detected pesticides.

\begin{tabular}{|c|c|c|c|c|c|c|c|}
\hline \multirow{2}{*}{ Pesticide } & \multicolumn{3}{|c|}{$\begin{array}{l}\text { Biobed Sump } \\
\text { Mean Concentration }\left(\mu \mathrm{g} \mathrm{L}^{-1}\right)\end{array}$} & \multicolumn{4}{|c|}{$\begin{array}{l}\text { Porous Pot } \\
\text { Mean Concentration }\left(\mu \mathrm{g} \mathrm{L}^{-1}\right)\end{array}$} \\
\hline & Input & Output & $\begin{array}{r}\text { Efficiency } \\
(\%)\end{array}$ & $45 \mathrm{~cm}$ & $\begin{array}{r}\text { Efficiency } \\
(\%)\end{array}$ & $90 \mathrm{~cm}$ & $\begin{array}{r}\text { Efficiency } \\
(\%)\end{array}$ \\
\hline Propyzamide & 2551.3 & 60.0 & 97.6 & - & - & - & - \\
\hline Chloridazon & 2547.7 & 81.9 & 96.8 & - & - & - & - \\
\hline Triclopyr & 958.5 & 32.8 & 96.6 & 1.2 & 96.3 & 2.5 & 92.4 \\
\hline Ethofumesate & 26935.1 & 980.9 & 96.4 & - & - & - & - \\
\hline Chlorotoluron & 150.4 & 6.9 & 95.4 & - & - & - & - \\
\hline Bromoxynil & 167.3 & 11.3 & 93.2 & 1.1 & 90.3 & 1.6 & 85.8 \\
\hline 2,4-D & 2944.9 & 213.7 & 92.7 & 2.2 & 99.0 & 6.5 & 97.0 \\
\hline Mecoprop & 803.7 & 112.7 & 86.0 & 3.0 & 97.3 & 6.6 & 94.1 \\
\hline MCPA & 30.4 & 4.8 & 84.2 & 1.1 & 77.1 & 1.6 & 66.7 \\
\hline Fluroxypyr & 1162.0 & 224.6 & 80.7 & 9.3 & 95.9 & 16.0 & 92.9 \\
\hline Dicamba & 223.5 & 43.8 & 80.4 & 9.1 & 79.2 & 13.9 & 68.3 \\
\hline Carbetamide & 15.3 & 3.0 & 80.4 & - & - & - & - \\
\hline Clopyralid & 1025.5 & 238.1 & 76.8 & 5.5 & 97.7 & 16.2 & 93.2 \\
\hline Metsulfuron-methyl & 32.9 & 8.1 & 75.4 & 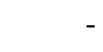 & - & - & . \\
\hline Metazachlor & 5561.0 & 1754.9 & 68.4 & - & - & - & - \\
\hline
\end{tabular}

8

9 Table 3: Approximate construction costs (including labour) for the Manor Farm biobed installed in 10 2013.

\begin{tabular}{lrrr} 
& \multicolumn{2}{c}{ Area } & \multicolumn{2}{c}{ Cost } \\
\cline { 2 - 4 } Component & $\left(\mathbf{m}^{\mathbf{2}}\right)$ & $\mathbf{( \mathbf { E } )}$ & $\left(\mathbf{( \mathbf { f ~ } \mathbf { ~ } ^ { - \mathbf { 2 } } )}\right.$ \\
Sprayer wash-down area & 270 & 90,454 & 335 \\
Biobed & 49 & 4311 & 88 \\
Drainage field & 200 & 1684 & 8 \\
Matrix replenishment after 2 years & 49 & 378 & 8 \\
\cline { 2 - 4 } & Total cost & $\mathbf{9 6 , 8 2 7}$ & \\
\hline
\end{tabular}




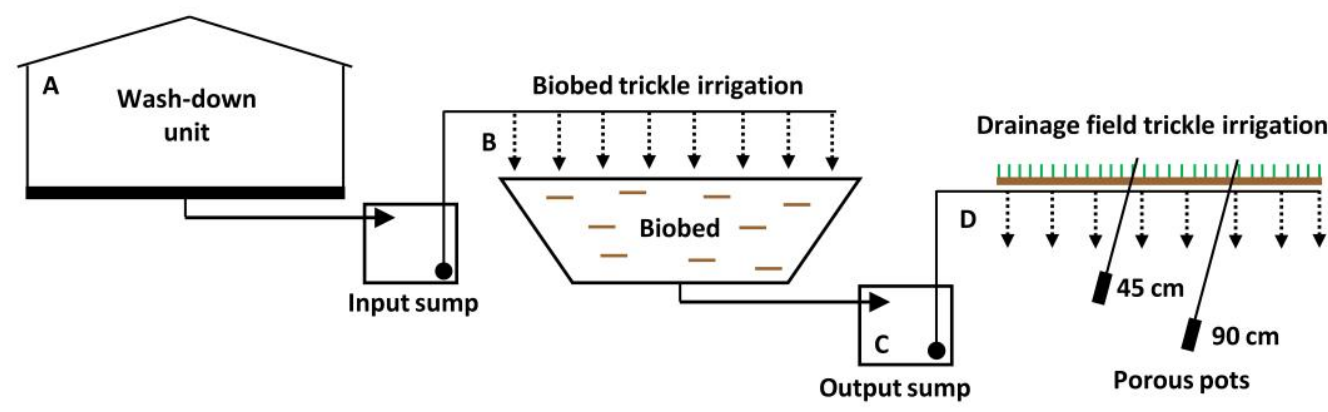

Figure 1: Schematic of the biobed unit installed at Manor Farm, Salle. Letters refer to the photographs in Figure 2.
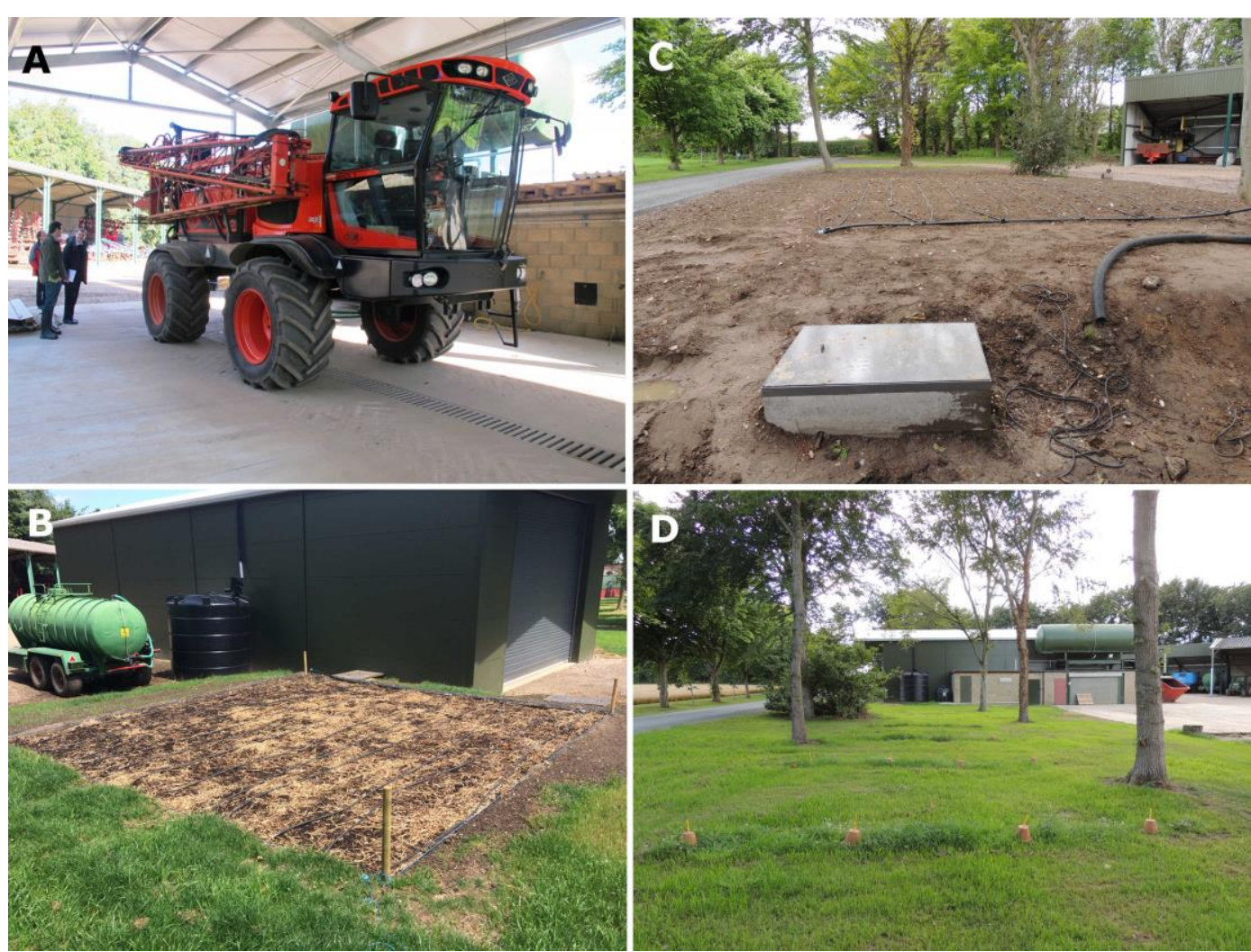

Figure 2: Images of the biobed facility installed at Manor Farm, Salle. (A) Pesticide sprayer inside the machinery wash-down unit during construction; (B) biobed operational area $(7 \mathrm{~m} \times 7 \mathrm{~m})$ with the completed enclosed wash-down unit in the background; (C) biobed output sump and trickle irrigation system during construction; (D) drainage field trickle irrigation area, with porous pot outlets located underneath terracotta pots. 


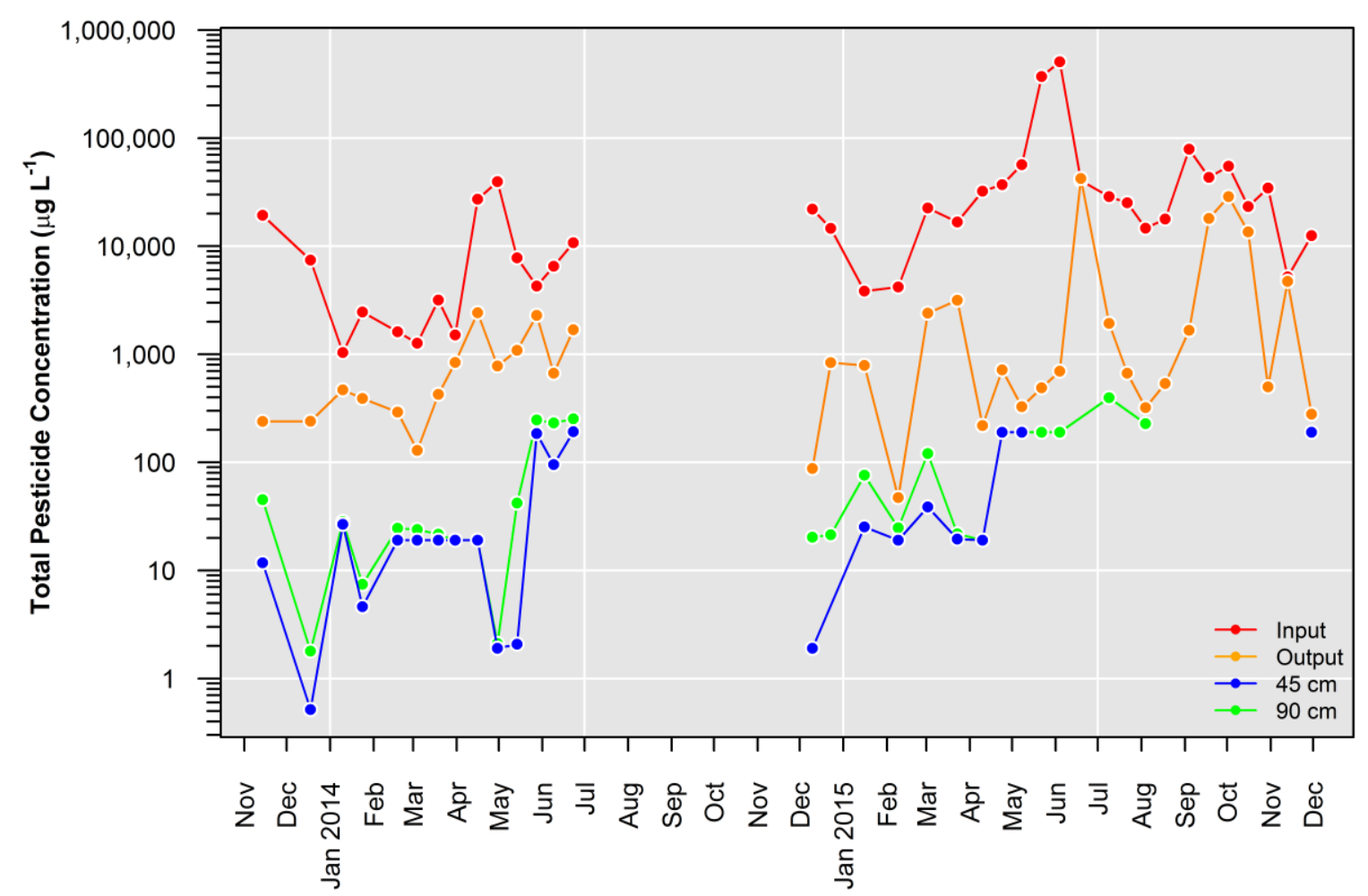

Figure 3: Total pesticide concentrations recorded in the input and output sumps and in the drainage field porous pots (45 cm and $90 \mathrm{~cm}$ depth) between November 2013 and November 2015.

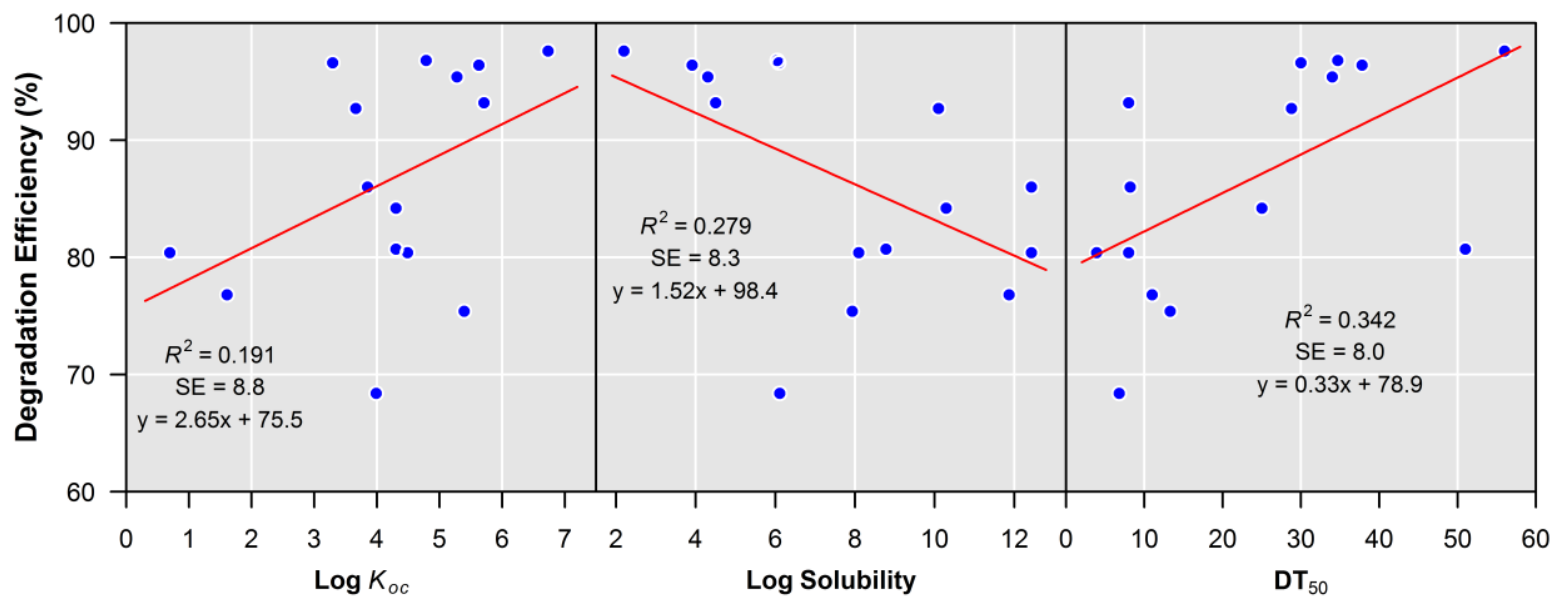

33 Figure 4: Linear regression relationships between biobed removal efficiency at the output sump and the typical physico-chemical properties of the 15 key pesticides monitored. Physico-chemical properties derived from Lewis et al. (2016). 